\title{
Recent developments in the chemistry and biology of epothilones
}

\section{Karl-Heinz Altmann, ${ }^{1, *}$ Frederic Cachoux, ${ }^{2,3}$ Giorgio Caravatti, ${ }^{2}$ Thomas Isarno, ${ }^{2,4}$ and Markus Wartmann²}

${ }^{1}$ Department of Chemistry and Applied Biosciences, Institute of Pharmaceutical Sciences, Swiss Federal Institute of Technology (ETH) Zürich and ${ }^{2}$ Novartis Institutes for Biomedical Research, DA Oncology E-mail: karl-heinz.altmann@pharma.ethz.ch

\begin{abstract}
Epothilones (Epo's) are bacterial natural products which are potent inhibitors of human cancer cell proliferation in vitro and in vivo. Tumor growth inhibition is based on the stabilization of cellular microtubules and at least seven epothilone-derived agents are presently undergoing clinical evaluation in humans. While all of these compounds are closely related structurally to the natural product leads Epo A and B, our own work involves the design, synthesis, and biological evaluation of analogs with significantly altered structural features. The ultimate goal of these efforts is the stepwise creation of new (and simplified) scaffolds for microtubule inhibition, bearing little or no obvious resemblance with the original epothilone structure. Such compounds would constitute new lead structures for anticancer drug discovery. In this paper we discuss the synthesis and biological properties of such hypermodified epothilone analogs, whose biological activity is within the same potency range as that of Epo A or B.
\end{abstract}

Keywords: Natural products, epothilones, microtubule stabilizer, anticancer, total synthesis, drug discovery

\section{Introduction}

Epothilones are 16-membered cytotoxic macrolides produced by the myxobacterium Sorangium cellulosum Sc 90, which were first reported by Reichenbach and Höfle in $1993^{1}$. There are two major variants of this class of natural products, termed epothilone A and epothilone B (Epo A and Epo B), which are distinguished by the presence or absence of a methyl group at C12 of the 16membered macrocycle (Figure 1). 

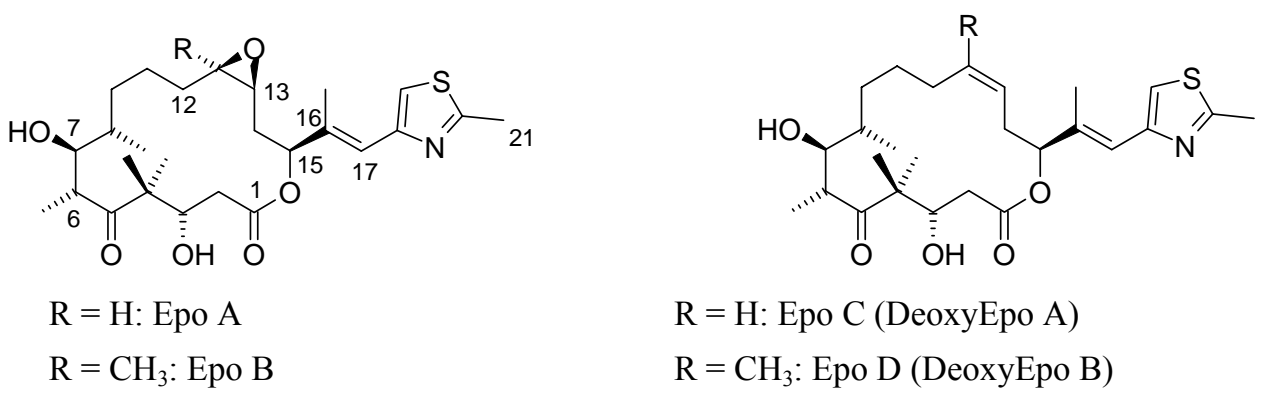

$\mathrm{R}=\mathrm{H}$ : Epo C (DeoxyEpo A)

$\mathrm{R}=\mathrm{CH}_{3}$ : Epo D (DeoxyEpo B)

Figure 1. Structures of Epothilones A-D.

Epothilones are potent cytotoxic agents which inhibit the growth of a variety of human cancer cell lines in vitro with $\mathrm{nM}$ or even sub-nM $\mathrm{IC}_{50}$ 's. ${ }^{2-4}$ Mechanistically, cytotoxicity arises from interference with cellular microtubule dynamics, resulting in abnormal spindle formation during mitosis and concomitant G2/M arrest followed by apoptosis. ${ }^{2-4}$ In cell-free in vitro systems, epothilones induce polymerization of tubulin heterodimers into microtubule-like polymers and they can stabilize preformed microtubules against cold- or $\mathrm{Ca}^{2+}$-induced depolymerization. ${ }^{2,3}$ Their mechanism of action is thus similar to that of the prominent anticancer drug paclitaxel (Taxol ${ }^{\circledR}$ ). However, in contrast to paclitaxel epothilones are potent growth inhibitors of drug-sensitive as well as multidrug-resistant cancer cell lines; ${ }^{2-4}$ in addition, they have been shown to be active in vitro against cell lines whose paclitaxel-resistance is derived from specific tubulin mutations. ${ }^{3,5}$ Epo B as well as a number of its analogs have been demonstrated to possess potent in vivo antitumor activity and at least seven compounds of this class are currently undergoing clinical evaluation in humans. ${ }^{6}$ These include Epo B itself (developed by Novartis), deoxyepothilone B (Epo D; Roche/Kosan/Sloan-Kettering Cancer Center), BMS-247550 (the lactam analog of Epo B; BMS), BMS-310705 (C21-amino-Epo B), ABJ879 (C20-Desmethyl-C20-methylsulfanyl Epo B) ${ }^{7}$ and a compound from Schering AG of unknown structure. ${ }^{8}$

One of the common characteristics of all the above clinical development compounds is their still close structural relationship with Epo B, which may perhaps limit the potential for pharmacological differentiation from the original natural product lead. In contrast to these closely related structures, our research is focused on generating more rigorously modified, but still potent, analogs, which we think are more likely to produce significant changes in overall pharmacological profile. The ultimate goal of these efforts is the evolution of hypermodified analogs (with very limited, if any, structural similarity with the original epothilone scaffold) that would represent new chemotypes for microtubule inhibition. This strategy can be considered the synthesis-based equivalent to the discovery of a new natural product with a specific biological activity. Within this conceptual framework, this paper will highlight three selected aspects of our epothilone-based drug discovery program, namely (i) the change of the geometry of the epoxide moiety from cis to trans, (ii) the rigidification of the unsaturated heterocycle-bearing side chain, and (iii) the removal of the C3hydroxyl group to produce 3-deoxyepothilone analogs, all of which represent elemental steps on the way to new chemotypes for microtubule inhibition. 


\section{Results and Discussion}

\section{Trans-epothilone A}

One of the most intriguing features of the epothilone SAR revealed during early SAR studies was the fact that even $\mathrm{C} 12 / \mathrm{C} 13$ trans-analogs of deoxyepothilones (Figure 1) exhibit very potent tubulin-polymerizing as well as antiproliferative activity. ${ }^{9-12}$ The literature data available at the outset of our own work in this area indicated that trans-deoxyEpo A was only slightly less active than deoxyEpo A (Figure 1), whereas in the B series the activity difference appeared to be more pronounced. At the same time, trans-Epo A was reported by Nicolaou et al. to be virtually equipotent with Epo A on an ovarian (1A9) and a breast cancer (MCF-7) cell line ${ }^{11}$ However, the absolute stereochemistry of the active epoxide isomer was not reported and the trans isomers were obtained as minor components during the synthesis of the natural cis isomers rather than being the result of a directed synthetic effort. In view of the interesting biological features of trans(deoxy)epothilones we embarked on a project directed at the stereoselective synthesis of transepothilones $\mathrm{A}$, the determination of the absolute stereochemistry of the bioactive isomer, and a more exhaustive biological characterization of this compound. ${ }^{13}$

The stereoselective synthesis of (12S, 13S)-trans-Epo A 1 is summarized in Scheme 1. ${ }^{[13]}$ The key step in the synthesis of this compound consists in the B-alkyl Suzuki coupling between olefin 5 and trans vinyl iodide 6, which in the presence of $\mathrm{Ph}_{3} \mathrm{As}$ as a ligand proceeded in $61 \%$ yield.
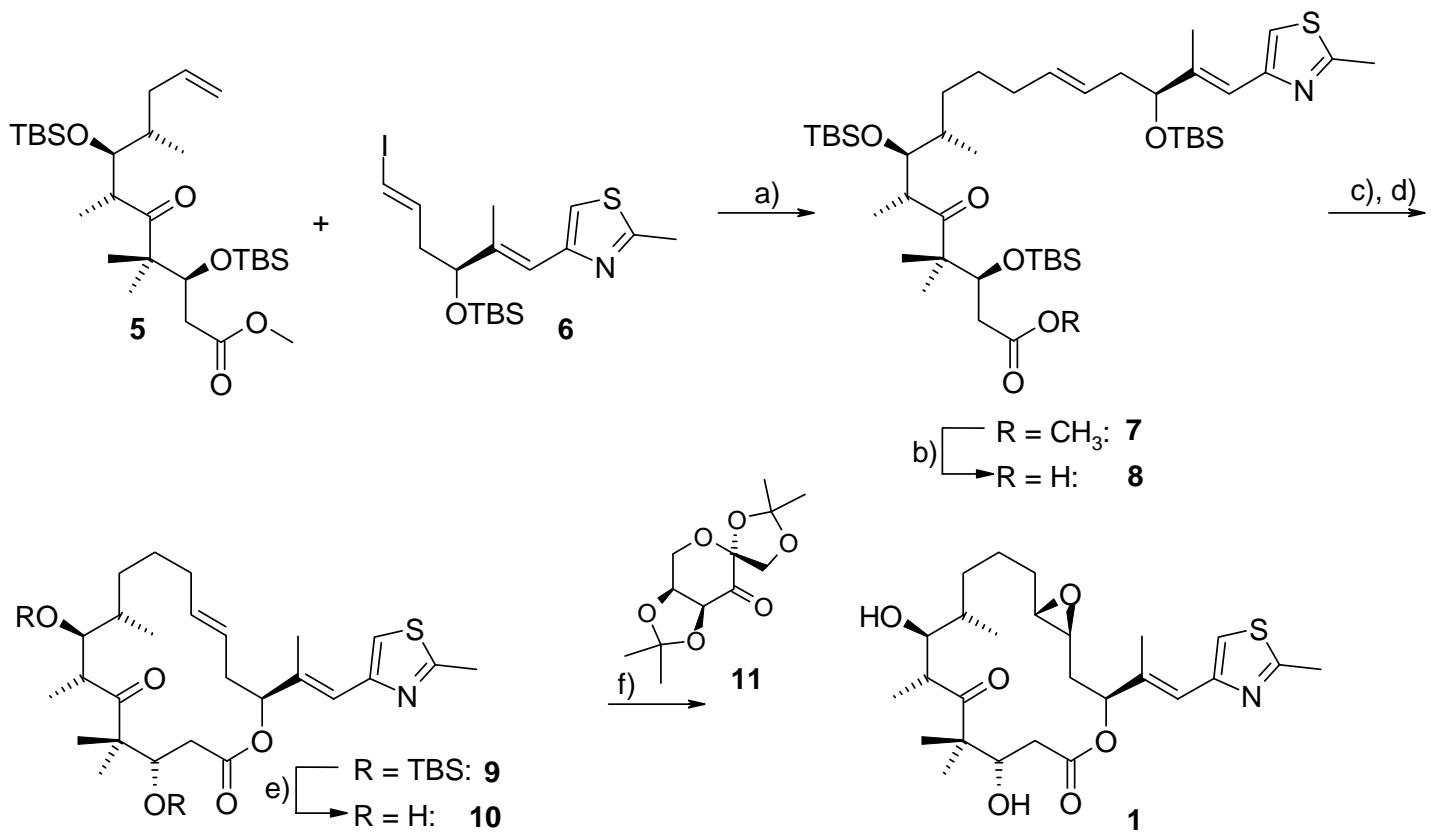

Scheme 1. a) i. Olefin 5, 9-BBN, THF, RT; ii. $\mathrm{Cs}_{2} \mathrm{CO}_{3}, \mathrm{PdCl}_{2}(\mathrm{dppf})_{2}, \mathrm{Ph}_{3} \mathrm{As}$, vinyl iodide 6, DMF, $10^{\circ} \rightarrow \mathrm{RT}, 63 \%$. b) $\mathrm{LiOH}, i-\mathrm{PrOH} / \mathrm{H}_{2} \mathrm{O} 4 / 1,50^{\circ}, 85 \%$. c) TBAF, THF, 64\%. d) $2,4,6-\mathrm{Cl}_{3} \mathrm{C}_{6} \mathrm{H}_{2} \mathrm{C}(\mathrm{O}) \mathrm{Cl}, \mathrm{Et}_{3} \mathrm{~N}$, DMAP, THF/toluene, 61\%. e) $\mathrm{CF}_{3} \mathrm{COOH} / \mathrm{CH}_{2} \mathrm{Cl}_{2}, 91 \%$. f) Oxone ${ }^{\circledR}, 11$ (30 mol-\%), $\mathrm{Bu}_{4} \mathrm{NHSO}_{4}$ (cat), $\mathrm{K}_{2} \mathrm{CO}_{3}, \mathrm{CH}_{3} \mathrm{CN} / \mathrm{DME} / 0.05 \mathrm{M} \mathrm{Na}_{2} \mathrm{~B}_{4} \mathrm{O}_{7} \cdot 10 \mathrm{H}_{2} \mathrm{O}$ in $4 \cdot 10^{-4} \mathrm{M} \mathrm{Na}_{2}$ EDTA $2 / 1 / 2$, RT, $1 \mathrm{~h}, 31 \%$ (dr ca. 8:1; 50\% recovered starting material). 
While conversion of the resulting coupling product 7 into trans-deoxyEpo A $\mathbf{1 0}$ proved to be straightforward and proceeded in 38\% overall yield (4 steps), the most critical step in the preparation of trans-Epo A was the stereo- and regioselective epoxidation of the C12/C13 trans double bond. After significant optimization work this problem could be solved by the use of fructose-based epoxidation catalyst 11, ${ }^{14}$ which allowed the preparation of $(12 S, 13 S)$ trans-Epo A 1 with $c a .8 / 1$ - 10/1 selectivity.

As illustrated by the data summarized in Table 1, compound 1, which retains the natural stereochemistry at $\mathrm{C} 13$, is a strong inducer of tubulin polymerization in vitro and exhibits potent antiproliferative activity, whereas its $(12 R, 13 R)$-isomer (1a) is at least 500-fold less active than $\mathbf{1}$. (12S,13S)-trans-Epo A 1 in fact shows slightly higher growth inhibitory activity than Epo A itself and we have observed this rank order of activity across a wide range of human cancer cell lines. ${ }^{13}$

Table 1. Induction of tubulin polymerization and growth inhibition of human carcinoma cell lines by $\mathrm{C} 12 / \mathrm{C} 13$ trans-epothilones $\mathrm{A}^{13}$

\begin{tabular}{cccc}
\hline & $\begin{array}{c}\text { \%Tubulin } \\
\text { Polymerization }^{\mathrm{a}}\end{array}$ & $\begin{array}{c}\mathrm{IC}_{50} \mathrm{~KB}-31 \\
{[\mathrm{nM}]^{\mathrm{b}}}\end{array}$ & $\begin{array}{c}\mathrm{IC}_{50} \mathrm{~KB}-8511 \\
{[\mathrm{nM}]^{\mathrm{b}}}\end{array}$ \\
\hline Epo B & 85 & 0.19 & 0.19 \\
Epo A & 63 & 2.00 & 1.79 \\
$\mathbf{1}$ & 85 & 1.00 & 0.87 \\
$\mathbf{1 a}^{\mathrm{c}}$ & $<10$ & 523 & 305 \\
\hline
\end{tabular}

${ }^{a}$ Induction of polymerization of porcine brain microtubule protein by $5 \mu \mathrm{M}$ of test compound relative to the effect of $25 \mu \mathrm{M}$ of Epo B, which gave maximal polymerization (85\% of protein input). ${ }^{\mathrm{b}} \mathrm{IC}_{50}$-values for growth inhibition of human epidermoid carcinoma cell lines $\mathrm{KB}-31$ and KB-8511. KB-8511 is a P-gp-overexpressing multidrug-resistant subline of the KB-31 parental line. ${ }^{\mathrm{c}} \mathbf{1} \mathbf{a}=(12 R, 13 R)$-trans-Epo A.

Whether the cis/trans equivalence observed for Epo A and trans-Epo A 1 also occurs in the Epo $\mathrm{B}$ series is unclear at this point, as the literature data on this question are somewhat contradictory (a 88-fold activity difference between Epo B and trans-Epo B against the human ovarian cancer cell line $1 \mathrm{~A} 9$ is reported in ref 11 , whereas a difference of only 8 -fold is reported in ref. 12 for the same cell line). On the other hand, our finding that the trans-Epo A scaffold of $\mathbf{1}$ is associated with potent biological activity has recently been confirmed and expanded by Nicolaou et al. for a series of highly potent C12/C13 cyclopropane-based analogs of $\mathbf{1 8} .^{15,16}$

\section{Conformationally constrained analogs}

A significant part of our analog program was directed at side-chain-modified analogs of epothilones. Apart from more conventional analogs incorporating an olefinic double bond as a linker between the macrolactone ring and different types of heterocycles, ${ }^{17}$ we have also studied a more significantly modified family of structures. The design of these analogs was primarily guided 
by the available information on the bioactive (tubulin-bound) conformation of Epo A as determined by NMR spectroscopy, which had indicated an exclusively transoid arrangement of the olefinic double bond between $\mathrm{C} 16 / \mathrm{C} 17$ and the $\mathrm{C}-\mathrm{N}$ bond of the thiazole ring ${ }^{18}$ (Figure 2).

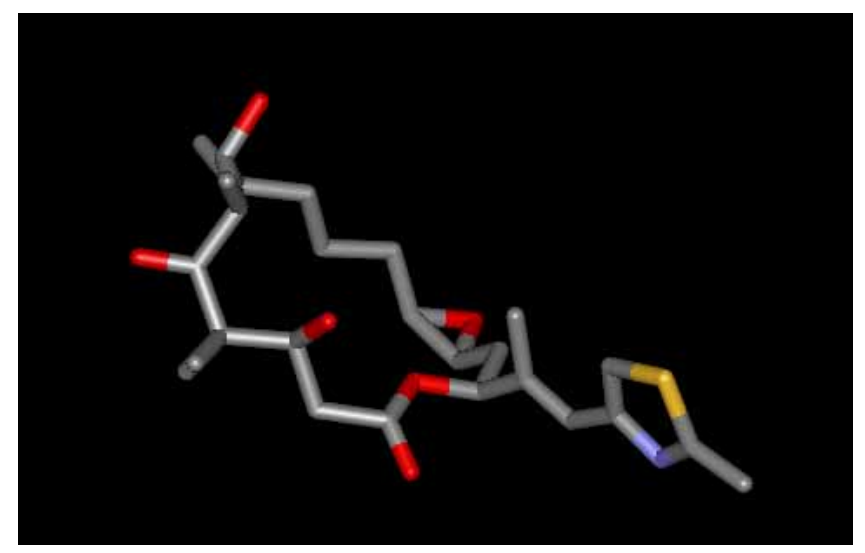

Figure 2. Tubulin-bound conformation of Epo A as determined by NMR spectroscopy (H-atoms are omitted for clarity). ${ }^{18}$

Stabilization of this bioactive side chain conformation through incorporation of the C16-C17 olefinic double bond into a properly designed fused hetero-aromatic ring system (i. e. elimination of rotation about the $\mathrm{C} 16$ - $\mathrm{C} 17$ bond) resulted in analogs such as 12a and 12b, which showed improved cellular activity over the corresponding parent compounds Epo D and B, respectively.

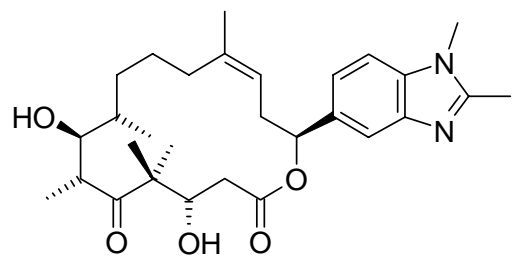

$12 \mathrm{a}$

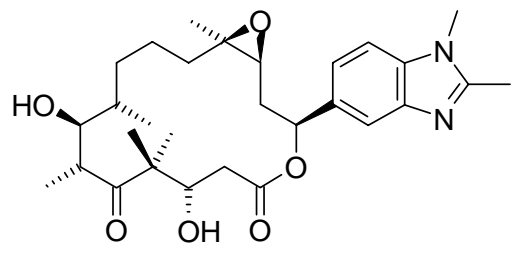

$12 b$

The activity-enhancing effect was particularly pronounced for the deoxy derivative 12a, which is $>10$-fold more potent against the human epidermoid carcinoma cell line KB-31 than Epo D. ${ }^{19}$ We have recently demonstrated that the beneficial effects of this side chain modification are not limited to analogs of the Epo B series, but are also observed for the corresponding Epo A derivatives. $^{20}$

With one of the major objectives of our analog program being the evolution of new templates for microtubule inhibition, we have subsequently prepared analogs, which combine a trans-epoxidecontaining epothilone macrocycle with the above dimethyl-benzimidazole side chain in a single molecule. The synthesis of the corresponding target structure 2 is summarized in Scheme 2 and is based on the B-alkyl Suzuki coupling between olefin 5 (Scheme 2) and vinyl iodide 15 as one of the key steps. 

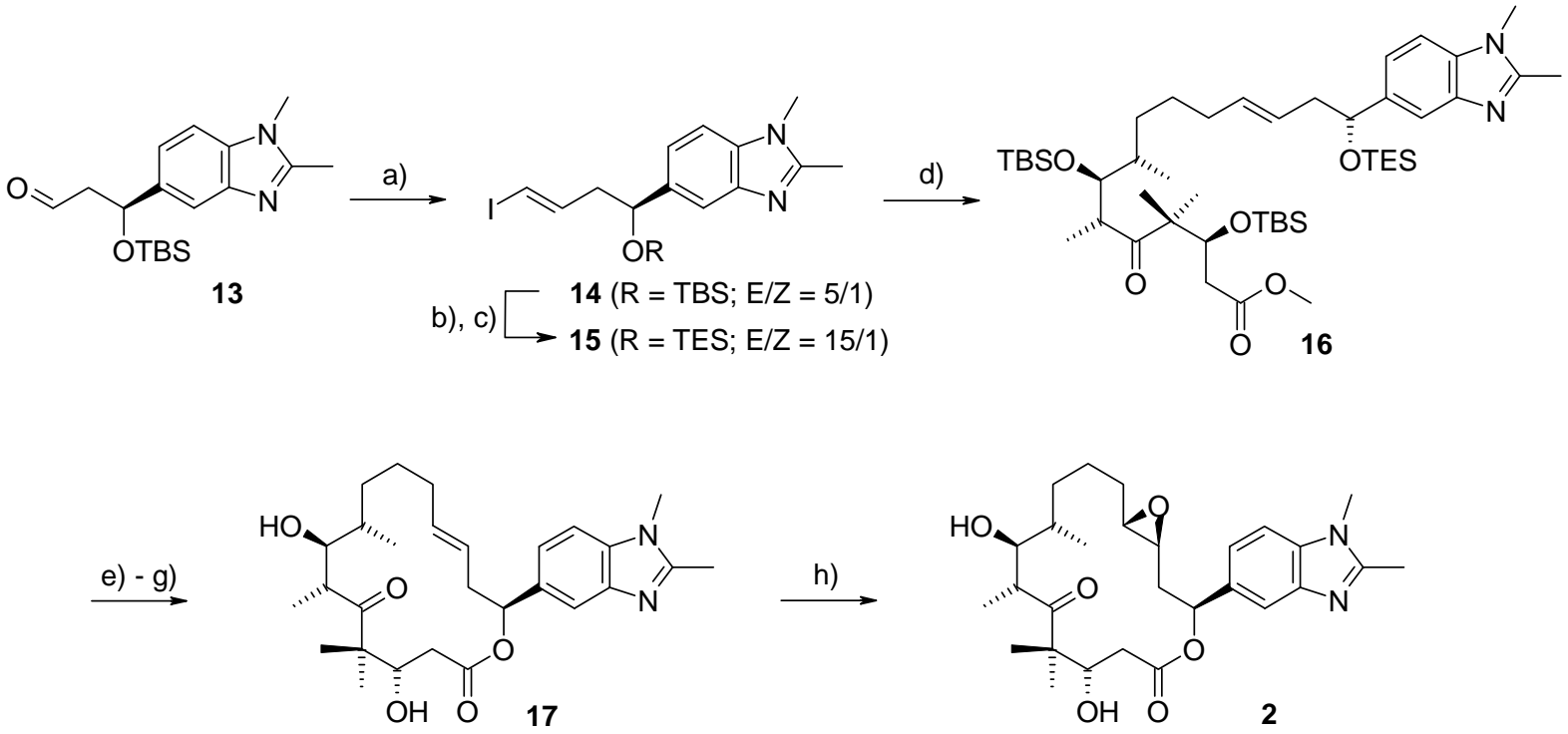

Scheme 2. a) $\mathrm{CHI}_{3}, \mathrm{CrCl}_{2}$, dioxane/THF $6 / 1,62 \%$; b) $\mathrm{CSA}, \mathrm{CH}_{2} \mathrm{Cl}_{2} / \mathrm{MeOH}$, crystallization from $\mathrm{CH}_{2} \mathrm{Cl}_{2} /$ hexane/MeOH, $43 \%$ (92\% for $5 / 1$ mixture of $\mathrm{E} / \mathrm{Z}$ isomers (14a) before crystallization); c) TES-Cl, imidazole, DMF, $0^{\circ} \mathrm{C}, 97 \%$; d) i. Olefin 5, 9-BBN, THF, RT, 2h; ii. $\mathrm{Cs}_{2} \mathrm{CO}_{3}, \mathrm{PdCl}_{2}(\mathrm{dppf})_{2}, \mathrm{Ph}_{3} \mathrm{As}$, vinyl iodide 15, DMF, $-10^{\circ} \mathrm{C} \rightarrow \mathrm{RT}, 55 \%$. e) $\mathrm{LiOH}, i-\mathrm{PrOH} / \mathrm{H}_{2} \mathrm{O} 4 / 1,50^{\circ} \mathrm{C}, 78 \%$; f) $2,4,6-\mathrm{Cl}_{3} \mathrm{C}_{6} \mathrm{H}_{2} \mathrm{C}(\mathrm{O}) \mathrm{Cl}, \mathrm{Et}_{3} \mathrm{~N}$, $\mathrm{THF}, 0^{\circ} \mathrm{C}, 15 \mathrm{~min}$, then dilution with toluene and addition to solution of DMAP in toluene, RT, 93\%; g) HFxpyridine, THF, RT, 80\%; h) Oxone ${ }^{\circledR}$, ketone 11 (cf. Scheme 1), $\mathrm{Bu}_{4} \mathrm{~N}\left(\mathrm{HSO}_{4}\right)$ (cat), $\mathrm{K}_{2} \mathrm{CO}_{3}$, $\mathrm{MeCN} / \mathrm{DMM} / 0.05 \mathrm{M} \mathrm{Na}_{2} \mathrm{~B}_{4} \mathrm{O}_{7} \cdot 10 \mathrm{H}_{2} \mathrm{O}$ in $4.10^{-4} \mathrm{M} \mathrm{Na}_{2}$ EDTA $1 / 1 / 1.3,0^{\circ} \mathrm{C}, 70 \%$.

Elaboration of the resulting coupling product into 2 proceeded through a similar sequence of steps as had been employed in the synthesis of $\mathbf{1}$. However, in contrast to the epoxidation of $\mathbf{1 0}$ (Scheme 1), the epoxidation of the corresponding deoxy precursor of 2 (i. e. 17) proceeded with much higher efficiency. Thus, treatment of $\mathbf{1 7}$ with an excess of oxone in the presence of 0.8 equiv of ketone 11 (Scheme 1) produced a 8/1 mixture of epoxide isomers (70\% yield after flash chromatography), from which 2 was isolated in pure form and 53\% overall yield through preparative HPLC. ${ }^{20}$ This yield significantly exceeds that obtained of trans-Epo A 1 after epoxidation of trans-Epo C (10; Scheme 1), partly because the separation of epoxide isomers proved to be more straightforward for 2 than for trans-Epo A 1, but also because of higher conversion in the epoxidation of $\mathbf{1 7}$ (as compared to trans-Epo C 10). Analog 2 proved to be a potent inducer of tubulin polymerization and a highly active inhibitor of human cancer cell growth. The antiproliferative activity of 2 against the human epidermoid carcinoma cell line KB-31 is comparable with that of Epo B and significantly exceeds the activity of either Epo A or trans-Epo A 1 ( $\mathrm{IC}_{50}$-values of $0.25 \mathrm{nM}$ (2), $2.15 \mathrm{nM}$ (Epo A), and $1.0 \mathrm{nM}$ (1), respectively). However, in contrast to Epo A or 1, analog 2 is at least a weak substrate for the P-gp efflux pump, as indicated by ca. 5fold reduced growth inhibitory activity against the P-gp-overexpressing, multidrug-resistant $\mathrm{KB}$ 8511 cell line (compared to its effects against the drug-sensitive KB-31 line; $\mathrm{IC}_{50}=1.36 \mathrm{nM}$ ). Nevertheless, benzimidazaole-based analog 2 is still far less susceptible to P-gp-mediated efflux 
than paclitaxel, for which the activity differential between KB-8511 and KB-31 cells is ca. 230fold. ${ }^{21}$ The reasons for the enhanced P-gp susceptibility of $\mathbf{2}$ are not understood, but the effect is in line with previous findings in our laboratory, which indicate that epothilone analogs with enhanced polarity (lower clog $\mathrm{P}$ values), including Epo $\mathrm{D}$ and $\mathrm{B}$ analogs 12a and 12b, generally are less active against P-gp-overexpressing cells (M. Wartmann, A. Flörsheimer, K.-H. Altmann, unpublished results). In agreement with these observations, preliminary data for analogs related to 2 that are more lipophilic in character indicate that the activity against resistant cells can be restored through additional structural modifications.

\section{3-Deoxyepothilones}

A different strategic starting point for our attempts to create hypermodified potent epothilone analogs was the removal of the hydroxyl group in the 3-position of the epothilone scaffold. Rather surprisingly, the consequences of this modfication for biological activity until recently had not been explicitly investigated in the literature, although other types of modifications at the 3-position had been described. Thus, $\alpha, \beta$-dehydration in Epo's $\mathrm{A}$ and $\mathrm{B}$ (leading to 3-deoxy-2,3-didehydro

derivatives) is well tolerated, ${ }^{4,22}$ which is in agreement with an anti-periplanar conformation of the C2-C3 bond in the proposed bioactive conformation of Epo A (cf. Figure 2). ${ }^{18}$ Activity is also largely retained upon replacement of the (3S)-hydroxyl group by a (3S)-cyano group, ${ }^{22}$ while inversion of configuration at $\mathrm{C} 3$ leads to a profound loss in biological potency (for both Epo's $\mathrm{A} / \mathrm{B}^{6 \mathrm{~d}}$ as well as the corresponding 3-deoxy-3-cyano analogs $\mathrm{s}^{22}$. Given the absence of biological information about simple 3-deoxy analogs of epothilones (with a single bond between $\mathrm{C} 2$ and $\mathrm{C} 3$ ), we have prepared 3-deoxyEpo B 3 and assessed the biological activity of this compound. The synthesis of 3 is summarized in Scheme 3 and follows similar strategic principles as had been employed in the preparation of $\mathbf{1}$ and $\mathbf{2} .^{23}$

Key steps are the B-alkyl Suzuki coupling of olefin $\mathbf{1 8}$ with vinyl iodide 20, Yamaguchi macrolactonization, and finally epoxidation of the $\mathrm{C} 12-\mathrm{C} 13$ double bond in deprotected macrolactone 21. Unexpectedly, macrolactonization was accompanied by partial epimerization at C15 (!), which later necessitated purification of 21 by preparative HPLC. Rather intriguingly, 3deoxyEpo B 3 showed potent tubulin-polymerizing and antiproliferative activity, such that its cellular activity against the human epidermoid cancer cell line KB-31 is only ca. 25 -fold lower than that of Epo B ( $\mathrm{IC}_{50}$-values of $7.4 \mathrm{nM}$ and $0.29 \mathrm{nM}$ for 3 and Epo B, respectively). ${ }^{23}$ The cellular potency of $\mathbf{3}$ is comparable with that of paclitaxel, Epo A, and also 3-deoxy-2,3-didehydro-Epo B, but in contrast to paclitaxel the compound retains activity also against multidrug-resistant KB-8511 cells (data not shown). The reduction in antiproliferative activity is more pronounced at the level of deoxy compound 21, which is $c a$. 40-fold less potent than Epo D. ${ }^{23}$ 

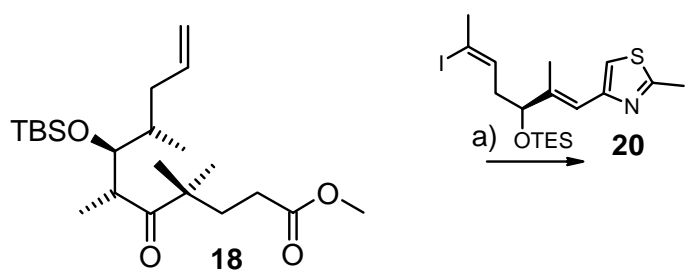
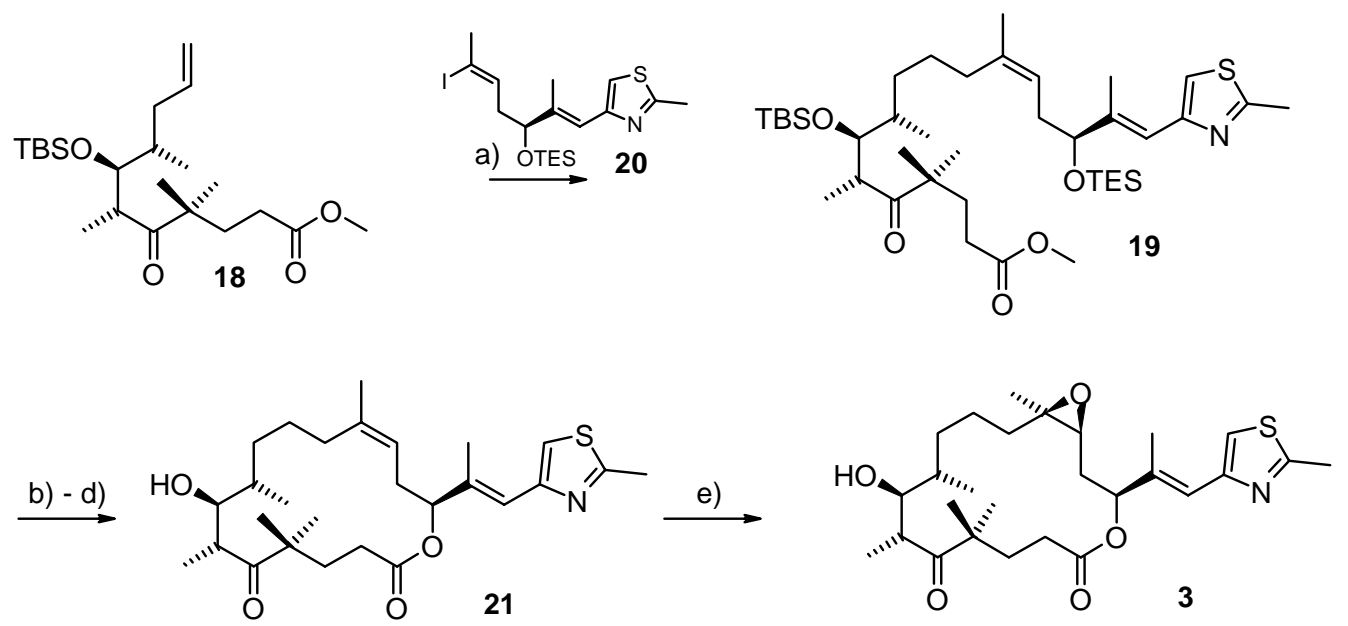

Scheme 3. a) 9-BBN, THF, RT, 2h; ii. $\mathrm{Cs}_{2} \mathrm{CO}_{3}, \mathrm{PdCl}_{2}(\mathrm{dppf})_{2}, \mathrm{Ph}_{3} \mathrm{As}$, vinyl iodide 20, DMF, $-10{ }^{\circ} \mathrm{C} \rightarrow \mathrm{RT}$, $55 \%$; b) $\mathrm{LiOH}, i-\mathrm{PrOH} / \mathrm{H}_{2} \mathrm{O} 4 / 1,60{ }^{\circ} \mathrm{C}, 98 \%$; c) 2,4,6- $\mathrm{Cl}_{3} \mathrm{C}_{6} \mathrm{H}_{2} \mathrm{C}(\mathrm{O}) \mathrm{Cl}, \mathrm{Et}_{3} \mathrm{~N}$, THF, $0^{\circ} \mathrm{C}, 15$ min, then diluted with toluene and added to a solution of DMAP in toluene, RT, $80 \%$ (2/1 mixture of epimers); d) HFxpyridine, THF, RT, 90\% (2/1 mixture of isomers; pure 21 obtained through purification by preparative HPLC); e) $\mathrm{MeReO}_{3}, \mathrm{H}_{2} \mathrm{O}_{2} /$ pyridine $/ \mathrm{H}_{2} \mathrm{O}, \mathrm{RT}, 72 \%$ (9/1 mixture of epoxide isomers; pure 3 obtained through purification by preparative HPLC).

In a next step we then asked, whether at least some of the activity loss incurred by the removal of the 3-hydroxyl group in Epo B could be recovered through additional and compensatory structural modifications. Based on our previous studies on potency-enhancing side-chain modifications (vide supra), ${ }^{19}$ this led to the design of compound 3a, which was found to be almost equipotent with Epo B with regard to growth inhibition of the KB-31 cell line $\left(\mathrm{IC}_{50}\right.$ of $0.58 \mathrm{nM} v \mathrm{~s}$. $0.29 \mathrm{nM}$ for Epo B).

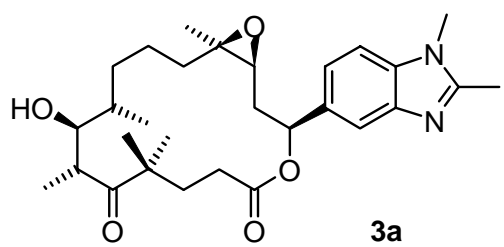

As previously observed for analog 2, compound 3a shows a small (3-4-fold), but clearly detectable activity differential between the sensitive KB-31 and the resistant KB-8511 cell line ( $\mathrm{IC}_{50}$ increase against the KB-8511 cell line to $1.58 \mathrm{nM}$ ), indicating that it may be a weak substrate for the P-gp efflux pump.

The structure of compound 3a deviates from that of Epo B with regard to both the core macrocycle as well as the heterocycle-bearing side chain, but it still features a cis-configured epoxide moiety at positions $12 / 13$, which is a major structural hallmark of the natural products. Given the potent biological activity of analog 2, the next logical step in our quest for potent hypermodified epothilone analogs thus was the design of compound 4 (Scheme 4), which combines 
all the different individual modifications discussed above within a single molecule. 4 was obtained from 18 via B-alkyl Suzuki coupling with vinyl iodide 15 (Scheme 2), elaboration of the coupling product into deoxy analog 22 and final epoxidation (Scheme 4).

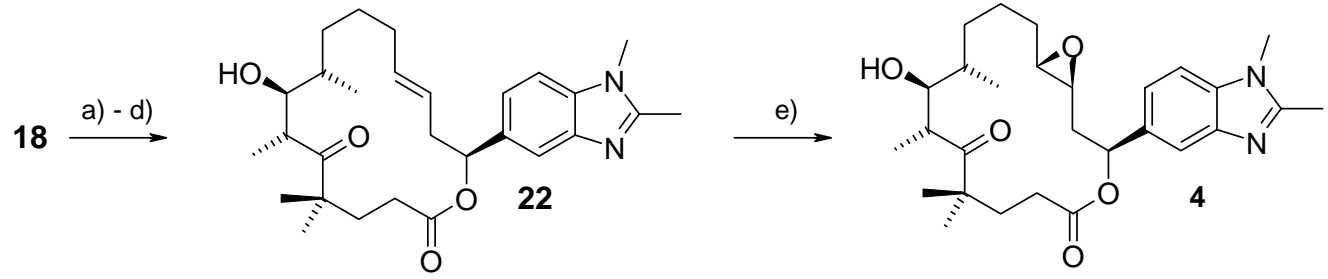

Scheme 4. a) 9-BBN, THF, RT, 2 h; ii. $\mathrm{Cs}_{2} \mathrm{CO}_{3}, \mathrm{PdCl}_{2}(\mathrm{dppf})_{2}, \mathrm{Ph}_{3} \mathrm{As}$ (0.2 eq), vinyl iodide 15, DMF, $10{ }^{\circ} \mathrm{C} \rightarrow \mathrm{RT}, 16 \mathrm{~h}, 58 \%$. b) $\mathrm{LiOH}, \mathrm{THF} / \mathrm{H}_{2} \mathrm{O} 7 / 1$, RT, 24h, 76\%. c) $2,4,6-\mathrm{Cl}_{3} \mathrm{C}_{6} \mathrm{H}_{2} \mathrm{C}(\mathrm{O}) \mathrm{Cl}, \mathrm{Et} \mathrm{t}_{3} \mathrm{~N}, \mathrm{THF}, 0{ }^{\circ} \mathrm{C}$, $15 \mathrm{~min}$, then diluted with toluene and added to a solution of DMAP in toluene, RT, 71\%. d) HFxpyridine, THF, RT, 94\%. e) Oxone ${ }^{\circledR}$, ketone 11 (0.8 equiv), $\mathrm{Bu}_{4} \mathrm{~N}\left(\mathrm{HSO}_{4}\right)$ (cat), $\mathrm{K}_{2} \mathrm{CO}_{3}, \mathrm{MeCN} / \mathrm{DMM} / 0.05 \mathrm{M}$ $\mathrm{Na}_{2} \mathrm{~B}_{4} \mathrm{O}_{7} \times 10 \mathrm{H}_{2} \mathrm{O}$ in $4 \times 10^{4} \mathrm{M} \mathrm{Na}_{2}$ EDTA $1 / 1 / 1.3,0{ }^{\circ} \mathrm{C}, 3 \mathrm{~h}, 65 \%$ (86\% based on recovered starting material; single isomer).

Quite remarkably, and in spite of its harboring major structural alterations relative to the native epothilone scaffold, the tubulin-polymerizing and antiproliferative activity of compound $\mathbf{4}$ is virtually identical with that of Epo A or paclitaxel ( $\mathrm{IC}_{50}$ of $\mathbf{4}$ against the drug-sensitive KB-31 cell line of $3.16 \mathrm{nM}$ ). As for $\mathbf{2}$ and 3, the growth inhibitory activity of $\mathbf{4}$ is slightly (ca. 2-fold) lower against the multidrug-resistant KB-8511 cell line than the paclitaxel-sensitive parental KB-31 line, but this small difference in cellular potency may not be pharmacologically relevant.

In summary, employing an iterative approach based on a natural product structural scaffold, we have derived a new microtubule-stabilizing agent, which we consider to represent a novel structural scaffold for microtubule inhibition. As such, 4 and related compounds may offer the same potential for pharmacological differentiation from the original epothilone leads as various newly discovered natural product microtubule inhibitors with macrolactone structure, such as laulimalide, peloruside, or dictyostatin. ${ }^{24}$ Future work will focus on synthesis scale-up and the extensive biological profiling of 4 and related structures in vitro and in vivo, in order to establish whether these compounds are in fact pharmacologically distinct from Epo A and B. At the same time we will assess the effects of further structural modifications of 4 in the $\mathrm{C} 8-\mathrm{C} 11$ region and at the 2-position of the benzimidazole nucleus, which may or may not mirror the effects observed for analogous modifications of Epo A and $\mathrm{B}$.

\section{Acknowledgements}

The work described in this paper was conducted at the Novartis Institute for Biomedical Research in Basel while KHA was still an employee of Novartis Pharma AG (until June 30, 2002). KHA is grateful to the company for the opportunity to conduct this research and to many colleagues for 
their collaboration and advice. With regard to the specific results described the authors are indebted to K. Hauenstein, T. Hatzinger, J. Köppler, M. Lartigot, K. Nathan, J. Loretan, R. Reuter, W. Vetterli, R. Vogelsanger, and S. Wojeik for their excellent technical assistance. FC and TI gratefully acknowledge financial support by Novartis Pharma AG through postdoctoral fellowships.

\section{References and Notes}

1. (a) Höfle, G.; Bedorf, N.; Gerth, K.; Reichenbach, H. German patent disclosure DE 4138042, May 5, 1993 (Priority Nov. 19, 1991). (b) Gerth, K.; Bedorf, N.; Höfle, G.; Irschik, H.; Reichenbach, H. J. Antibiotics 1996, 49, 560.

2. Bollag, D. M.; McQueney, P. A.; Zhu, J.; Hensens, O.; Koupal, L.; Liesch, J.; Goetz, M.; Lazarides, E.; Woods, C. M. Cancer Res. 1995, 55, 2325.

3. Kowalski, R. J.; Giannakakou, P.; Hamel, E. J. Biol. Chem. 1997, 272, 2534.

4. Altmann, K.-H.; Wartmann, M.; O'Reilly, T. Biochim. Biophys. Acta 2000, 1470, M79.

5. Giannakakou, P.; Sackett, D. L.; Kang, Y. K.; Zhan, Z., Buters, J. T.; Fojo, T.; Poruchynsky, M. S. J. Biol. Chem. 1997, 272, 17118.

6. For reviews $c f$., e. g.: (a) Altmann, K.-H. Curr. Pharm. Des. 2005, 11, 1595. (b) Altmann, K.-H. Org. Biomol. Chem. 2004, 2137. (c) Harris, C. R.; Danishefsky, S. J. J. Org. Chem. 1999, 64, 8434.(d) Nicolaou, K. C.; Roschangar, F.; Vourloumis, D. Angew. Chem. Intl. Ed. 1998, 37, 2014.

7. Zhou, Y. et al. AACR 96th Annual Meeting 2005, Anaheim, CA, USA, Abstract \#2535.

8. Schmid, P.; Kiewe, P.; Kuehnhardt, D.; Korfel, A.; Lindemann, S.; Giurescu, M.; Reif, S.; Thiel, E.; Possinger, K. J. Clin. Oncology (ASCO Annual Meeting Proceedings, No 16S (June 1 Supplement)) 2005, 23, 2051.

9. Meng, D.; Su, D. S.; Balog, A.; Bertinato, P.; Sorensen, E. J.; Danishefsky, S. J.; Zheng, Y. H.; Chou, T. C.; He, L.; Horwitz, S. B. J. Am. Chem. Soc. 1997, 119, 2733.

10. Su, D. S.; Balog, A.; Meng, D.; Bertinato, P.; Danishefsky, S. J.; Zheng, Y. H.; Chou, T. C.; He, L.; Horwitz, S. B. Angew. Chem. Int. Ed. 1997, 36, 2093.

11. Nicolaou, K. C.; Winssinger, N.; Pastor, J.; Ninkovic, S.; Sarabia, F.; He, Y.; Vourloumis, D.; Yang, Z.; Li, T.; Giannakakou, P.; Hamel, E. Nature 1997, 387, 268.

12. Nicolaou, K. C.; Vourloumis, D.; Li, T.; Pastor, J.; Winssinger, N.; He, Y.; Ninkovic, S.; Sarabia, F.; Vallberg, H.; Roschangar, F.; King, N. P.; Finlay, M. R.; Giannakakou, P.; Verdier-Pinard, P.; Hamel, E. Angew. Chem. Int. Ed. 1997, 36, 2097.

13. Altmann, K.-H.; Bold, G.; Caravatti, G.; Denni, D.; Flörsheimer, A.; Schmidt, A.; Rihs, G.; Wartmann, M. Helv. Chim. Acta 2002, 85, 4086.

14. Tu, Y.; Wang, Z.-X.; Shi, Y. J. Am. Chem. Soc. 1996, 118, 9806.

15. Nicolaou, K. C.; Namoto, K.; Ritzen, A.; Ulven, T.; Shoji, M.; Li, J.; D'Amico, G.; Liotta, D.; French, C. T.; Wartmann, M.; Altmann, K.-H.; Giannakakou, P. J. Am. Chem. Soc. 2001, 123, 9313. 
16. Nicolaou, K. C.; Ritzen, A.; Namoto, K.; Ruben, M. B.; Diaz, F.; Andreu, J. M.; Wartmann, M.; Altmann, K.-H.; O’Brate, A.; Giannakakou, P. Tetrahedron 2002, 58, 6413.

17. Nicolaou, K. C.; Scarpelli, R.; Bollbuck, B.; Werschkun, B.; Pereira, M. M.; Wartmann, M.; Altmann, K.-H.; Zaharevitz, D.; Gussio, R.; Giannakakou, P. Chem. Biol. 2000, 7, 593.

18. Carlomagno, T.; Blommers, M. J. J.; Meiler, J.; Jahnke, W.; Schupp, T.; Petersen, F.; Schinzer, D.; Altmann, K.-H.; Griesinger, C. Angew. Chem. 2003, 115, 2615.

19. Altmann, K.-H.; Bold, G.; Caravatti, G.; Flörsheimer, A.; Guagnano, V.; Wartmann, M. Bioorg. Med. Chem. Lett. 2000, 10, 2765.

20. Cachoux, F.; Isarno, T.; Wartmann, M.; Altmann, K.-H. Chem. Bio. Chem. 2006, 7, 54.

21. Wartmann, M.; Altmann, K.-H. Curr. Med. Chem: Anti-Cancer Agents 2002, 2, 123.

22. (a) Regueiro-Ren, A.; Leavitt, K.; Kim, S.-H.; Höfle, G.; Kiffe, M.; Gougoutas, J. Z.; DiMarco, J.; Lee, F. Y. F.; Fairchild, C. R.; Long, B. H.; Vite, G. D. Org. Lett. 2002, 4, 3815. (b) Altmann, K.-H.; Wartmann, M.; O'Reilly, T. Biochim. Biophys. Acta 2000, 1470, M79.

23. Cachoux, F.; Isarno, T.; Wartmann, M.; Altmann, K.-H. Angew. Chem. Intl. Ed. 2005, 44, 7469.

24. For recent reviews on microtubule stabilizing agents $c f$., e. g. (a) Altmann, K.-H. Curr. Opin. Chem. Biol. 2001, 5, 424. (b) Myles, D. C. Ann. Rep. Med. Chem. 2002, 37, 125. 